\title{
A Case of Nasal Septal and Oral Cavity Abscesses Resulting from Mucormycosis in an Immunocompromised Patient
}

\author{
Han Kyung Sung, Ju Chang Kang, and Jee Hye Wee \\ Department of Otorhinolaryngology-Head and Neck Surgery, Bundang Jesaeng General Hospital, Daejin Medical Center, \\ Seongnam, Korea
}

\section{면역저하 환자에서 발생한 털곰팡이증에 의한 비중격 및 구강 농양 1 예}

성한경 · 강주창 · 위지혜

대진의료재단 분당제생병원 이비인후-두경부외과

\author{
Received September 21, 2018 \\ Revised October 24, 2018 \\ Accepted October 29, 2018 \\ Address for correspondence \\ Jee Hye Wee, MD \\ Department of Otorhinolaryngology- \\ Head and Neck Surgery, \\ Bundang Jesaeng General Hospital, \\ Daejin Medical Center, \\ 20 Seohyeon-ro 180beon-gil, \\ Bundang-gu, Seongnam 13590 , \\ Korea \\ Tel +82-31-779-0682 \\ Fax +82-31-779-0265 \\ E-mail weejh07@hanmail.net
}

\begin{abstract}
Mucormycosis is a rare invasive and highly aggressive fungal infection, which shows rapid progression with life threatening complications in immunocompromised patients. Therefore, it is important to quickly recognize fungal infection in immunocompromised patients and start treatment with antifungal agents or perform surgical debridement. Most nasal septal abscesses are caused by post-traumatic hematoma and subsequent bacterial infection. In immunocompromised patients, nasal septal abscess can develop without trauma and may involve atypical pathogens like fungus. Herein we report a case of mucormycosis presenting with abscesses of nasal septum and gingivobuccal mucosa in an immunocompromised patient.
\end{abstract}

Korean J Otorhinolaryngol-Head Neck Surg 2019;62(9):524-8

Key Words Abscess · Immunocompromised host · Mucormycosis · Nasal septum.

\section{서 론}

털곰팡이증(mucormycosis)은 병의 진행 속도가 빠르고 특 히 면역저하 환자에서 치명적인 경과를 보이는 혈관 침윤성 감염증으로 초기의 적절한 치료가 환자의 예후에 매우 중요 하다.) 비안와뇌형(rhino-orbital-cerebral)이 가장 많고, 폐나 위장관, 여러 장기를 침범하는 파종형(disseminated), 피부감 염 등으로 나타나며, 주로 조절되지 않은 당뇨병, 혈액종양, 장기간 면역억제제 사용 등 환자의 면역저하가 있을 때 발생 한다. 털곰팡이증의 진단은 진균을 조직병리학적으로 확인

This is an Open Access article distributed under the terms of the Creative Commons Attribution Non-Commercial License (https://creativecommons.org/licenses/by-nc/4.0) which permits unrestricted non-commercial use, distribution, and reproduction in any medium, provided the original work is properly cited.
하는 것이 필수적이며, 병변 부위 조직이나 흡인 검체에서 균 사가 넓고 격막이 없으며 수직 모양으로 분지하는 것이 특징이 다. ${ }^{2}$ 치료는 외과적 괴사조직절제술과 항진균제를 사용하는 것이며, amphotericin B의 사용이 추천되고 posaconazole 을 사용할 수도 있다. ${ }^{3}$

비중격 농양은 대부분 외상에 의해 발생하며 대부분 절개 및 배농과 적절한 항생제 치료로 치유되지만, 면역저하 환자 에서는 외상없이 발생할 수 있으며 치명적인 합병증이 발생할 가능성이 높다. ${ }^{4)}$ 저자들은 중증 재생불량성 빈혈(aplastic anemia)로 줄기세포이식(stem cell transplantation) 후 면역억제 치료 중 이식편대숙주병(graft-versus-host disease) 발생으로 스테로이드 치료를 병행하던 환자에서 털곰팡이증에 의한 비 중격과 잇몸-볼 점막(gingivo-buccal mucosa)에 동시에 발 
생한 농양 1 예를 경험하였기에 문헌고찰과 함께 보고하는 바 이다.

\section{증 례}

44세 여자 환자가 혈액종양 내과 입원 중 3일 전 갑자기 발 생한 양측 코막힘과 통증으로 이비인후과에 의뢰되었다. 환자 는 재생불량성 빈혈로 3주 전 줄기세포이식 후 면역억제 치료 (fludarabine/cyclophosphamide)를 받고 있었으며, 이식편 대숙주병 발생으로 스테로이드 치료를 병행하고 있었고, 외상 의 과거력은 없었다. 줄기세포이식 후 예방적으로 광범위 항생 제(trimethoprim/sulfamethoxazole)를 투여받고 있었다. 1 주일 전 좌측 하악 구치 부위에 통증 발생하여 치성 감염 감 별 위해 경부 컴퓨터단층촬영 하였고, 농양 및 괴사가 있어 치과에서 반복적인 괴사조직제거 치료 중에 있었다. 의뢰 당 시 이학적 검사상 좌측 하악 대구치 주변으로 잇몸과 점막의 괴사 및 농양과 양측 비중격 미부의 종창(Fig. 1)이 있었고,
18 게이지 바늘로 비중격을 천자하여 흡입 시 농성 분비물이 나왔으며 이에 대해 세균 배양 및 그람염색을 시행하였다. 이 러한 비중격 농양은 1 주일 전 촬영한 경부 컴퓨터단층촬영 에서는 보이지 않던 소견이었다. 원인 감별을 위해 부비동 컴 퓨터단층촬영을 시행하였고, 1 주일 전 시행하였던 전산화단 층촬영과 비교하여 좌측 잇몸-볼 점막과 구강저 부위의 농 양 및 공기 음영은 증가된 소견 관찰되었고, 비중격 미부에 2 $\times 1.3 \mathrm{~cm}$ 크기의 농양(Fig. 2)이 새롭게 관찰되었다. 비중격 농양으로 진단하고 전신마취 하 절개 배농술을 시행하였다. 좌측 비강을 통해 비중격에 hemitransfixion 절개를 하자 농 성 분비물이 나왔으며 이에 대해 세균 배양 및 그람염색을 시행하였고, 비중격 연골이 부분적으로 괴사(Fig. 3A)되어 있어 이에 대해 조직검사를 시행하였다. 베타딘액과 식염수 로 세척 후 좌측 비중격 점막에 silastic sheet를 이용하여 배 액 구멍을 만들고 수술을 종료하였다. 수술 후 2일째 비내시 경 검사상 비중격 종창이 감소한 것을 관찰할 수 있었다 (Fig. 3B and C). 수술 후 4일째 배액구멍은 잘 유지되고 농
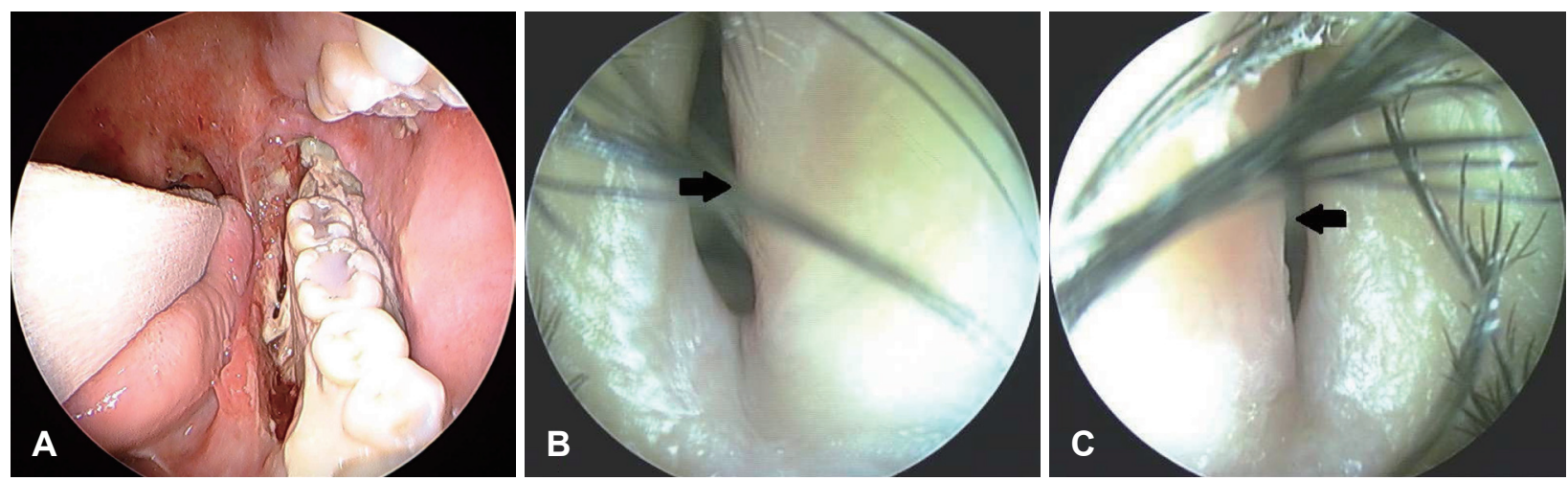

Fig. 1. Preoperative endoscopic findings. Necrosis of left gingiva (A). Bulging of nasal septum (arrows, $B$ and $C$ ) obscures both nasal cavity. Right nasal cavity (B). Left nasal cavity (C).

Fig. 2. Paranasal CT scans. Multifocal air densities (white arrow) in the mandible and abscess (black arrow) at left lower gingivobuccal space (A). Newly appeared $2 \times 1.3$ $\mathrm{cm}$ sized abscess (white arrow) is shown at anterior nasal septum (B).
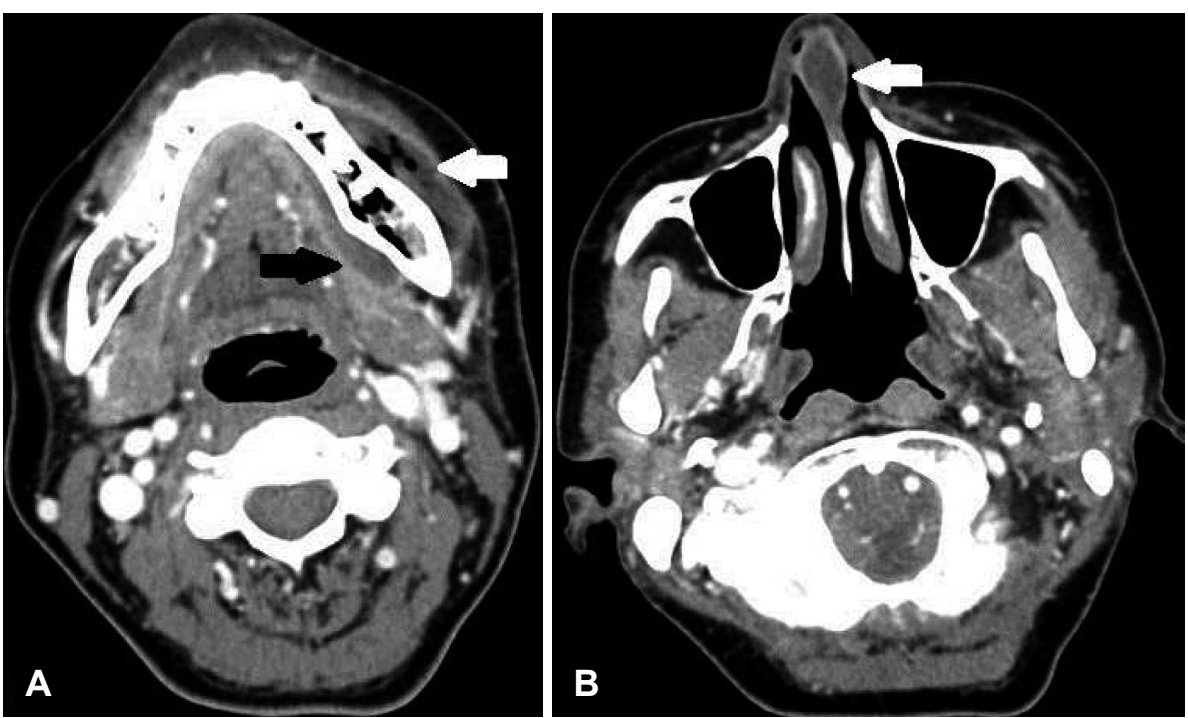

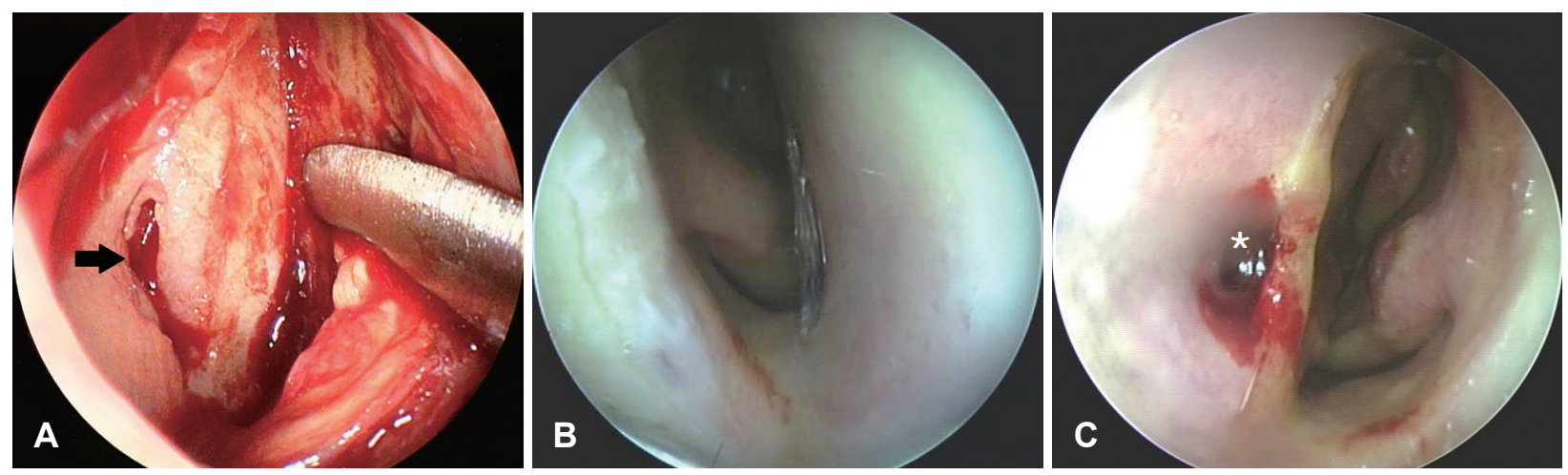

Fig. 3. Endoscopic findings. Operative finding shows necrosis (arrow) of septal cartilage (A). Right nasal cavity (B). Left nasal cavity (C). Postoperative endoscopic finding shows improving state of septal bulging and patency of drain hole (asterisk, C).
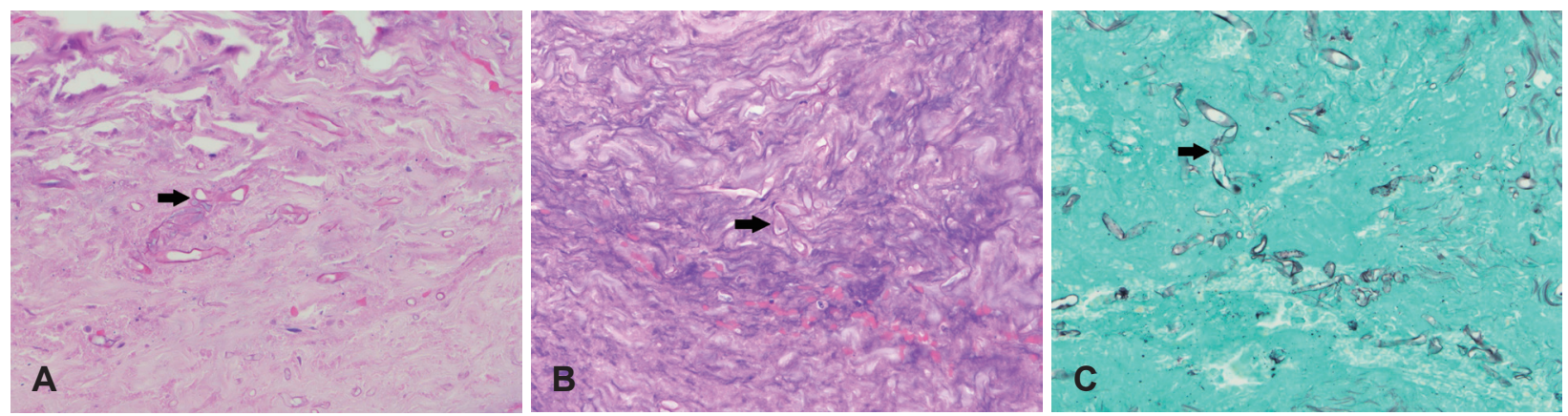

Fig. 4. Histologic findings. Non-septated, broad, ribbon-like fungal hyphae (arrow) were identified in necro-inflammatory exudate (hematoxylin and eosin stain, $\times 400)\left(\right.$ A). Many non-septated hyphae with branching at $90^{\circ}$ (arrows) suggestive of Mucormycosis was observed (periodic acid-schiff stain, $\times 400)(B)$ and (gomori methenamine-silver stain, $\times 400)(C)$.

양이 관찰되지 않아 silastic sheet를 제거하였으며, 배양검사 에서 동정되는 균은 없었다. 병리 조직검사상 hematoxylin and eosin 염색에서 격막이 없으며 수직 모양으로 분지하는 진균(Fig. $4 \mathrm{~A}$ )이 발견되어 털곰팡이증으로 진단되었다. 이에 정맥 amphotericin B 치료를 시작하였고, 좌측 하악 대구치 주위의 괴사조직에 대해서도 조직검사를 시행 후 주변부를 추가 제거하였다. Periodic acid-schiff 염색에서는 붉게 염 색되고 gomori methenamine-silver 염색에서 검은색으로 염색되는 격막 없이 수직으로 분지하는 진균(Fig. $4 \mathrm{~B}$ and C) 으로 털곰팡이증에 합당한 소견이었으며, 잇몸-볼 점막에서 시행한 조직검사에서도 같은 결과로 털곰팡이증에 의한 다 발성 농양으로 진단할 수 있었다. 다른 부위의 침범 여부를 확인하기 위해 시행한 부비동 자기공명영상에서 양측 부비 동을 포함하여 안와, 해면정맥동, 두개저, 뇌 실질 등에 이상 소견은 없었고, 비중격 미부에 관찰되었던 농양은 보이지 않 았으며 좌측 하악 대구치 주변의 농양도 감소된 것을 볼 수 있었다(Fig. 5). 비중격 농양은 재발 없이 호전된 상태로 유지 되었고 구강 내 괴사부위도 조금씩 호전되던 중, 전신적 항진 균제 사용에 따른 신독성과 전해질 이상 등 전신 부작용이 발생하여 amphotericin B는 중단하였으며, 수술 후 34일째 환자는 pseudomonas에 의한 패혈증 쇼크로 중환자실에서
호흡부전으로 사망하였다.

\section{고 찰}

비중격 농양은 비중격의 골-연골과 골막-연골막 사이에 농 양이 생기는 것으로 대부분 세균이 원인균이지만, 진균에 의해 발생한 경우들도 드물게 보고되고 있다. ${ }^{5-9)}$ 이들은 모두 외상 없이 면역저하 환자에서 발생한 비중격 농양으로 Aspergillus 종, Fusarium종, Candida albicans 이 검출되었으나, 본 증례와 같이 mucormycosis가 주 원인균으로 보고된 경우는 없었다. 비중격 농양은 즉각적으로 절개 배농술과 경험적 항생제 치 료를 시작해야 하며 그람염색 및 배양검사를 시행하여 감수 성이 있는 항생제 치료를 하여야 한다. 적절한 항생제 치료에 도 반응이 없을 경우, 특히 면역저하 환자의 경우 진균성일 가능성이 있으므로 추가로 조직학적 검사가 필요하다. 배양검 사에서도 포자낭을 확인할 수 있지만 시간이 오래 걸리고 배 양률이 낮기 때문에 조직검사로 균사를 확인하는 것이 필요 하다. 본 증례에서도 구강 내 발생한 농양에 대해 반복적인 괴 사 제거술과 함께 광범위 항생제(trimethoprim/sulfamethoxazole)를 투여함에도 호전을 보이지 않았으며 새롭게 비중격 농양이 발생하면서 조직검사를 통해 진균에 의한 농양임을 
Fig. 5. Paranasal sinus MRI images. Abscess at left mandibular gingivobuccal space is decreased in T1 weighted axial image (A). There is no evidence of remnant septal abscess in T1 weighted axial image (B).
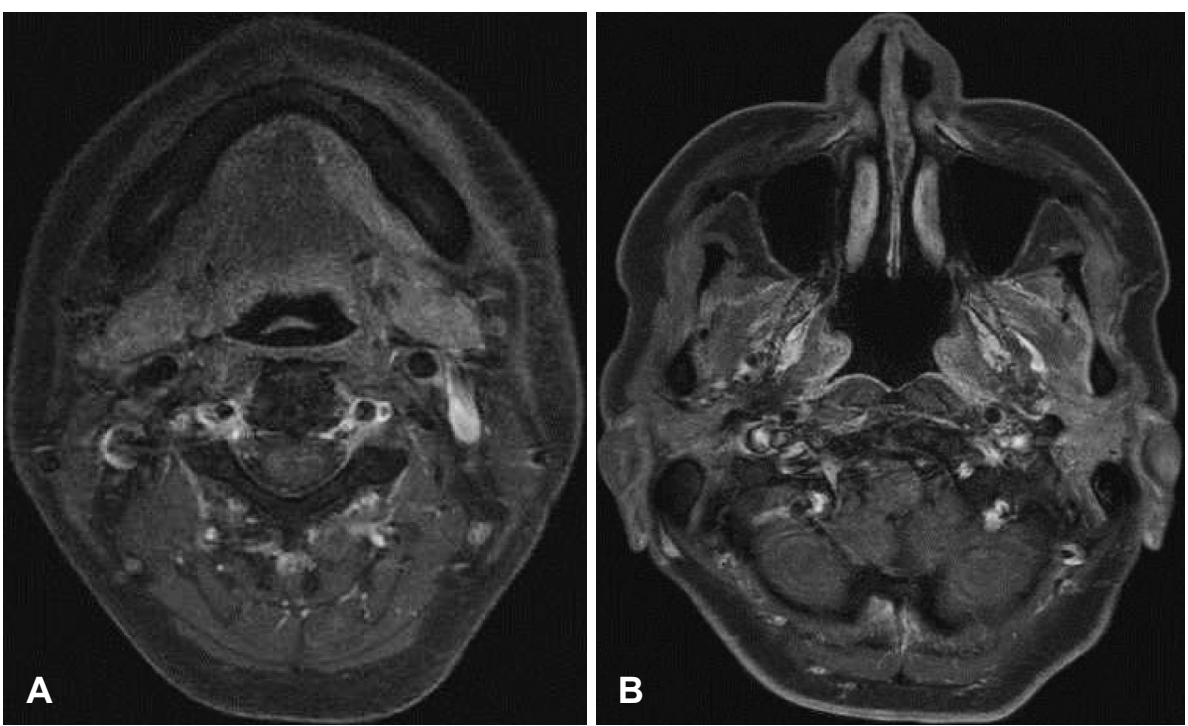

\section{진단할 수 있었다.}

진균에 의한 비중격 농양은 주로 당뇨병이나 면역억제 치료 를 받고 있는 환자에게서 발생하며, 뇌막염, 뇌농양, 해면 정 맥동 혈전증, 안와 합병증 등의 심각한 합병증이 더 빠르고 치 명적으로 발생할 수 있다. 전방 비중격 정맥은 구개의 정맥과 소 통하며 결국 안면 및 안정맥과 연결되어 해면정맥동(carvernous sinus)까지 소통되며, 후방 정맥은 익돌근 정맥총(pterygoid plexus)과 연결된다. 이처럼 비강 내 풍부한 정맥 네트워크로 인해 두개내로 전파될 위험이 높고, 진균이 혈관벽을 침투하 게 되면 혈전과 경색을 유발하여 조직의 허혈과 괴사를 유발 하게 되며 패혈증이나 다발성 장기 부전이 발생될 수 있다. ${ }^{10)}$ 자기공명영상은 털곰팡이증에서 이러한 해면정맥동 혈전증, 두개저, 뇌실질의 경색 등이 동반되어 있는지 확인하는데 유 용하다. ${ }^{11,12)}$ 본 증례에서는 털곰팡이증이 늦게 진단되어 자기 공명영상을 비중격 농양 절개 및 배액술 이후 시행하긴 하였 지만, 주위 조직으로의 침범은 관찰되지 않았다.

털곰팡이증은 amphotericin B로 치료한 경우 $61 \%$, 수술적 치료만 시행한 경우 $57 \%$, 수술적 치료와 항진균제 병행 치료 의 경우 $70 \%$ 의 높은 생존율을 보이기 때문에, 수술적 치료와 항진균요법의 병행이 추천된다. ${ }^{1)}$ 또한 호중구는 진균의 집락 화(colonization)에 대한 숙주의 방어기전에 있어 중요한 역할 을 하는 것으로 알려져 있기 때문에, 호중구 감소증이 흔히 동 반되는 백혈병 환자에서 진균 감염이 발생할 확률이 높아지 며, 조절되지 않는 당뇨병 환자에서도 케톤산증(ketoacidosis) 이 진균이 자라기 좋은 환경을 만들기 때문에, ${ }^{13)}$ 이러한 환자 의 기저질환을 치료해주는 것도 고려되어야 한다. 본 증례에 서 즉각적인 수술적 배농 및 괴사된 연골조직 제거와 함께 항진균제를 투여하여 농양 부위는 호전되는 추세이긴 했지
만, 환자는 이식편대숙주병 발생으로 면역억제제 및 스테로 이드 치료를 중단할 수 없었고 전신적 항진균제의 부작용도 동반되면서 기저질환이 악화되어 결국 사망하게 되었다.

본 증례의 환자는 기저질환에 의해 사망하는 결과를 보이 긴 하였지만, 항진균제 투여 및 수술적 배농과 괴사 조직 제 거를 통해서 농양이 치료가 되고 있었다. 면역저하환자에게 농양이 발생하였을 경우 진균에 의한 발생 가능성을 염두에 두고 빠른 조직검사 및 수술적 절제를 시행하는 것이 중요하 겠다.

\section{ORCID}

Jee Hye Wee https://orcid.org/0000-0002-6513-7011

\section{REFERENCES}

1) Roden MM, Zaoutis TE, Buchanan WL, Knudsen TA, Sarkisova TA, Schaufele RL, et al. Epidemiology and outcome of zygomycosis: A review of 929 reported cases. Clin Infect Dis 2005;41(5):634-53.

2) Medoff G, Kobayashi GS. Pulmonary mucormycosis. N Engl J Med 1972;286(2):86-7.

3) Langner S, Staber PB, Neumeister P. Posaconazole in the management of refractory invasive fungal infections. Ther Clin Risk Manag 2008; 4(4):747-58

4) Ambrus PS, Eavey RD, Baker AS, Wilson WR, Kelly JH. Management of nasal septal abscess. Laryngoscope 1981;91(4):575-82.

5) Cho IK, Chung YJ. A case of nasal septal abscess caused by combined bacterial and fungal infection in the immunocompromised patient. Korean J Otorhinolaryngol-Head Neck Surg 2012;55(6):378-81.

6) Debnam JM, Gillenwater AM, Ginsberg LE. Nasal septal abscess in patients with immunosuppression. AJNR Am J Neuroradiol 2007; 28(10):1878-9.

7) Dornbusch HJ, Buzina W, Summerbell RC, Lass-Flörl C, Lackner H, Schwinger W, et al. Fusarium verticillioides abscess of the nasal septum in an immunosuppressed child: Case report and identification of the morphologically atypical fungal strain. J Clin Microbiol 2005;43(4): 1998-2001. 
8) Jeong JH, Kim HO, Lee YS, Chung JH. A case of fungal nasal septal abscess in the immunocompromised patient. Korean J Otorhinolaryngol-Head Neck Surg 2008;51(11):1061-4.

9) Walker R, Gardner L, Sindwani R. Fungal nasal septal abscess in the immunocompromised patient. Otolaryngol Head Neck Surg 2007; 136(3):506-7.

10) Ribeiro NF, Cousin GC, Wilson GE, Butterworth DM, Woodwards RT. Lethal invasive mucormycosis: Case report and recommendations for treatment. Int J Oral Maxillofac Surg 2001;30(2):156-9.
11) McLean FM, Ginsberg LE, Stanton CA. Perineural spread of rhinocerebral mucormycosis. AJNR Am J Neuroradiol 1996;17(1): 114-6.

12) Herrera DA, Dublin AB, Ormsby EL, Aminpour S, Howell LP. Imaging findings of rhinocerebral mucormycosis. Skull Base 2009; 19(2):117-25.

13) Damante JH, Fleury RN. Oral and rhinoorbital mucormycosis: case report. J Oral Maxillofac Surg 1998;56(2):267-71. 